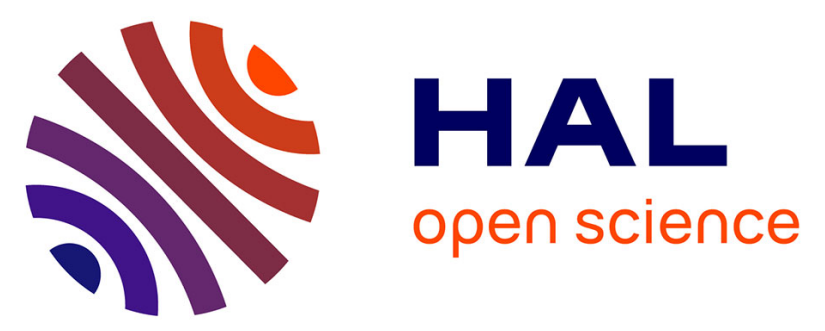

\title{
Characterization of fifteen microsatellite loci in the cone and seed-feeding insect, Pissodes validirostris, and cross-priming among congeneric species
}

David de Feraudy, Magally Torres-Leguizamon, Carole Kerdelhue, Geraldine Roux-Morabito

\section{To cite this version:}

David de Feraudy, Magally Torres-Leguizamon, Carole Kerdelhue, Geraldine Roux-Morabito. Characterization of fifteen microsatellite loci in the cone and seed-feeding insect, Pissodes validirostris, and cross-priming among congeneric species. Conservation Genetics Resources, 2014, 6 (2), pp.393-395. 10.1007/s12686-013-0101-8 . hal-02633873

\section{HAL Id: hal-02633873 \\ https://hal.inrae.fr/hal-02633873}

Submitted on 27 May 2020

HAL is a multi-disciplinary open access archive for the deposit and dissemination of scientific research documents, whether they are published or not. The documents may come from teaching and research institutions in France or abroad, or from public or private research centers.
L'archive ouverte pluridisciplinaire HAL, est destinée au dépôt et à la diffusion de documents scientifiques de niveau recherche, publiés ou non, émanant des établissements d'enseignement et de recherche français ou étrangers, des laboratoires publics ou privés.

\section{(c) (1) $\$$}

Distributed under a Creative Commons Attribution - NonCommercial| 4.0 International 


\title{
Characterization of fifteen microsatellite loci in the seed-feeding insect, Pissodes validirostris, and cross-priming among congeneric species.
}

\author{
D. de Feraudy ${ }^{1}$, M. Torres-Leguizamon ${ }^{1}$, C. Kerdelhué ${ }^{2}$ and G. Roux-Morabito ${ }^{1}$ \\ ${ }^{1}$ INRA, UR633 Zoologie forestière, 45075 Orléans cedex 2, France \\ ${ }^{2}$ INRA, UMR CBGP (INRA/IRD/CIRAD/Montpellier Supagro), F-34988 Montferrier-sur-Lez, \\ France
}

Word count (including title, abstract, keywords, main text and tables) : 780 .

\begin{abstract}
Fifteen microsatellite markers were developed for Pissodes validirostris. The number of alleles per locus ranged from two to 13 and observed heterozygosity from 0.033 to 0.900 . These markers will be useful to confirm the infra-specific phylogeographic patterns of this seed-feeding weevil, potential vector of the pitch canker disease of pine trees, thereby threatening their genetic resources. Most cross-species amplification was successful among the seven congeneric species tested.
\end{abstract}

Keywords: Microsatellites;genetic diversity;pine-cone weevil;Pissodes validirostris

Seed-feeding insects are responsible for important damages in managed forests or seed orchards (Turgeon et al. 1994), impacting the regeneration dynamics and genetic resources of coniferous trees. The pine-cone weevil, Pissodes validirostris (Coleoptera, Curculionidae), has a wide Palearctic distribution from Europe to north eastern China. It completes its larval development only in cones and seeds of Eurasian and Mediterranean Pinus species. In addition of limiting the regeneration of pine trees, this seed-feeding insect can transmit the highly virulent fungus, Fusarium circinatum, an important pathogen of Pinus seedlings recently introduced in Europe (Romon et al. 2007). Microsatellite markers would be useful for investigating phylogeographic structure and gene flow between populations of $P$. validirostris, in order to adapt pest management strategies.

Genomic DNA was extracted from 20 heads and thorax of adults collected in various localities and hosts using the DNeasy Tissue Kit (Qiagen). Two different procedures were used to develop polymorphic microsatellites. A set of five microsatellites loci were firstly designed following a biotin-enrichment protocol described in Kerdelhué et al (2003). Out of the 127 positive clones, 40 candidate microsatellites were selected for subsequent PCR from which five were polymorphic. In a second step, we used next generation sequencing 
combining DNA enrichment procedures with the use of multiplexed microsatellite probes and the update Titanium of the 454 GS-FLX technology (Malausa et al. 2011). Among the initial set of 980 potential microsatellite loci designed for this species, 10 polymorphic loci were finally selected on the 24 primer pairs tested (performed by Genoscreen, Lille, France). The fifteen loci retained were grouped in five multiplex (Table 1) and amplified on 30 individuals of $P$. validirostris collected on Pinus sylvestris near Cayrols (France). The amplifications were performed for each individual using a Veriti ${ }^{\circledR}$ 96-Well Fast and a 9800 Fast Thermal Cyclers (Applied Biosystems ${ }^{\circledR}$ ) and the Thermo Scientific DreamTaq DNA Polymerase package. Technical details and GenBank accession numbers are given in Tables 1 and 2.

For the first set of five loci, amplifications were performed in a $10 \mu \mathrm{L}$ volume of reaction containing < $40 \mathrm{ng}$ of DNA, following the procedure described in Kerdelhué et al. (2003). For the 10 loci developed by Genoscreen, amplifications were performed in a volume of $25 \mu \mathrm{L}$ containing < $40 \mathrm{ng}$ of DNA, $1 \mathrm{U}$ of DreamTa $q$ DNA Polymerase (Fermentas), $1.875 \mu \mathrm{L}$ of 10X DreamTaq buffer including $20 \mathrm{mM} \mathrm{MgCl}_{2}, 0.60 \mu \mathrm{L}$ of $20 \mathrm{mM}$ dNTP, 0.10 to $0.50 \mu \mathrm{L}$ of $20 \mu \mathrm{M}$ primers (Table 2) and distilled water. $25 \%$ of the forward primer of each primer set was 5'end-labelled with a fluorescent dye (either 6-FAM, VIC, PET or NED, Applied Biosystems ${ }^{\circledR}$ ). The amplified products were detected on an ABI 3500 Genetic Analyzer automatic sequencer using GeneScan ${ }^{\mathrm{TM}}-600 \mathrm{LIZ}^{\circledR}$ Size Standard v2.0 (Applied Biosystems ${ }^{\circledR}$ ) to size alleles, and then analyzed using the GENEMAPPER ${ }^{\circledR}$ software v4.1 (Applied Biosystems $^{\circledR}$ ).

Deviations from Hardy-Weinberg equilibrium (HWE), expected and observed heterozygosity and linkage disequilibrium were calculated using GENEPOP v 4.2 (Raymond and Rousset, 1995). The existence of null alleles was tested using MICROCHECKER (http://www.microchecker.hull.ac.uk/).

Genetic diversity indices are provided for each locus in Table 1. The number of alleles per locus ranged from two to 13 and the expected heterozygosity from 0.095 to 0.883 . Five loci revealed a significant excess of homozygotes that could be linked with signs of null alleles for these loci, or could be due to sampling biases associated with the low dispersal rate of this species. Cross amplification was also tested for seven congeneric species, including three out of the five European species, and several of the serious pests of pine plantations in North America, i.e. P. strobi and P. nemorensis (also introduced in South Africa), and in China, i.e. $P$. punctatus and P. yunnanensis. Amplifications were successful, except for three loci (Pis10, Pis17 and Pis23), which failed for all species but $P$. validirostris (Table 3). These microsatellite loci will facilitate the study of the genetic structure and the dispersal patterns of this seed-feeding insect.

\section{Acknowledgements}

This work was supported by the ANR PHYLOSPACE 2009. 


\section{References}

Kerdelhué C, Mondor-Genson G, Rasplus JY, Robert A and Lieutier F (2003)

Characterization of 5 microsatellite loci in the pine shoot beetle Tomicus piniperda (Coleoptera: Scolytidae). Mol Ecol Notes 3(1): 100-101.

Malausa T, Gilles A, Meglécz E et al. (2011) High-throughput microsatellite isolation through 454 GS-FLX Titanium pyrosequencing of enriched DNA libraries. Mol Ecol Res. 11:638644.

Raymond M, Rousset F (1995) GENEPOP (version 2): Population genetics software for exact tests and eucumenicism. J of Hered 86:248-249.

Romon P, Iturrondobeitia JC, Gibson K, Lindgren BS \& Arturo Goldarazena A (2007) Quantitative association of Bark Beetles with Pitch Canker fungus and effects of verbenone on their semiochemical communication in Monterey Pine forests in Northern Spain. Environ Entomol 36(4): 743-750.

Turgeon JJ, Roques A, de Groot P (1994) Insect fauna of coniferous seed cones - diversity, host-plant interactions, and management. Ann Rev of Entomol 39:179-212.

\section{Table captions :}

Table 1 Microsatellite data and polymorphism characterization of the P.validirostris population from Cayrols.

Table 2 Polymerase Chain Reaction conditions.

Table 3 Cross-species amplification results for Pissodes spp.: number of successful amplifications / number of alleles in the taxon. 
Table 1 Microsatellite data and polymorphism characterization of the P.validirostris population from Cayrols.

$N$ : number of individuals tested

\begin{tabular}{|c|c|c|c|c|c|c|c|c|c|}
\hline Locus & Primer sequences $\left(5^{\prime} \rightarrow 3^{\prime}\right)$ & Motif & Multiplex & $\begin{array}{l}\text { Expected } \\
\text { size (bp) }\end{array}$ & $N_{\mathrm{A}}$ & $\begin{array}{l}\text { Null allele } \\
\text { frequency }\end{array}$ & $\boldsymbol{H}_{O}$ & $H_{\mathrm{E}}$ & $P$ \\
\hline PS03 & $\begin{array}{l}\text { F: VIC-AGATCGACAGATCTCCAACAAG } \\
\text { R: AAATGCCTCTCGGACTGATG }\end{array}$ & $(\mathrm{GAA})_{7}$ & M1 & 109 & 4 & 0.0212 & 0,600 & 0,632 & 0,913 \\
\hline PS04 & $\begin{array}{l}\text { F: PET-TGTTAATCGCCAACGTCTGC } \\
\text { R: CAGCAATTTGCAATGCTTTCAC }\end{array}$ & $(\mathrm{GAA})_{8}$ & M1 & 129 & 4 & -0.0739 & 0,733 & 0,648 & 0,813 \\
\hline PS05 & $\begin{array}{l}\text { F: NED-AAGGAGGCTAAATACAACGGAC } \\
\text { R: AGAGGTCAGCATGGGGATATAG }\end{array}$ & $(\mathrm{GAA})_{8}$ & M1 & 129 & 6 & -0.0538 & 0,833 & 0,756 & 0,736 \\
\hline PS06 & $\begin{array}{l}\text { F: NED-GCTGCCGGATGAAGATAAATAG } \\
\text { R: TAACCCGATTACTTGAAAACGC }\end{array}$ & $(\mathrm{GAA})_{9}$ & M2 & 143 & 5 & 0.0761 & 0,433 & 0,503 & 0,634 \\
\hline PS08 & $\begin{array}{l}\text { F: 6-FAM-GTTAAGATGGCGAGATATATAG } \\
\text { R: GACGGAACTGCAGTCTGATC }\end{array}$ & $(\mathrm{GAA})_{16}$ & M2 & 148 & 11 & 0.0271 & 0,767 & 0,818 & 0,258 \\
\hline Pis16 & $\begin{array}{l}\text { F: 6-FAM-AGCGGTTGTTCGAAAATCAT } \\
\text { R: TGATCACATGTACGGCTGAAA }\end{array}$ & $(\mathrm{TC})_{12}$ & M3 & 160 & 12 & -0.0087 & 0,900 & 0,883 & 0,866 \\
\hline Pis 18 & $\begin{array}{l}\text { F: VIC-AATCAGACCCAGTTTGGTGC } \\
\text { R: TTCTTCCCCACCTGTAATCAA }\end{array}$ & $(\mathrm{AC})_{14}$ & M3 & 184 & 8 & 0.0505 & 0,667 & 0,731 & $0,014 *$ \\
\hline Pis19 & $\begin{array}{l}\text { F: NED-GATTGAGGAGGCCAAAGCTC } \\
\text { R: TTTGATTGAGAGGGTAGGCA }\end{array}$ & $(\mathrm{GTA})_{14}$ & M3 & 133 & 9 & 0.0519 & 0,733 & 0,802 & 0,584 \\
\hline Pis04 & $\begin{array}{l}\text { F: 6-FAM-ACTCTATTATTGGTTTGTCTATGACG } \\
\text { R: AAAGTATAACAACTGCCTTTCCG }\end{array}$ & $(\mathrm{GAC})_{7}$ & M4 & 141 & 2 & 0.1529 & 0,200 & 0,320 & $0,040^{*}$ \\
\hline Pis21 & $\begin{array}{l}\text { F: VIC-ACAGGTTGACGAACAGAGGAA } \\
\text { R: CTAAAGCCGCGACACAAAAT }\end{array}$ & $(\mathrm{AG})_{17}$ & M4 & 113 & 13 & 0.0537 & 0,633 & 0,691 & $0,003 * *$ \\
\hline Pis 10 & $\begin{array}{l}\text { F: PET-GGCTTTTATGGGAAGTAACCA } \\
\text { R: GCAAGGGAGACCTATGTCCA }\end{array}$ & $(\mathrm{TCT})_{9}$ & M4 & 125 & 3 & 0.1111 & 0,433 & 0,566 & 0,155 \\
\hline Pis12 & $\begin{array}{l}\text { F: NED-GATAATTTGTCATGGCAGCG } \\
\text { R: TTCCGAGTAACGTCTTTCCC }\end{array}$ & $(\mathrm{CA})_{9}$ & M4 & 192 & 2 & 0.1487 & $\mathbf{0 , 0 3 3}$ & 0,095 & $0,000^{* * *}$ \\
\hline Pis 23 & $\begin{array}{l}\text { F: 6-FAM-ACATTGGGTCATAAGGTGC } \\
\text { R: TTCTTTGGTCTGAATGAGAGTGA }\end{array}$ & $(\mathrm{GA})_{20}$ & M5 & 104 & 13 & 0.2056 & 0,500 & 0,861 & $0,000^{* * * *}$ \\
\hline Pis17 & $\begin{array}{l}\text { F: VIC-ATACCGCAACTTCCAAAGGA } \\
\text { R: AAACTGGACATGTGCTTCC }\end{array}$ & $(\mathrm{TCT})_{13}$ & M5 & 141 & 6 & 0.0973 & 0,467 & 0,581 & $0,024 *$ \\
\hline Pis07 & $\begin{array}{l}\text { F: NED-CCGCGTATAAATCAAGGGTT } \\
\text { R: GGTATAGATTATAACCTGGGTCGG }\end{array}$ & $(\mathrm{GA})_{8}$ & M5 & 160 & 4 & 0.0261 & 0,500 & 0,546 & 0,094 \\
\hline
\end{tabular}

$N_{\mathrm{A}}: \overline{\text { number of alleles; } H_{\mathrm{O}} \text { : observed heterozygosity; } H_{\mathrm{E}} \text { : expected heterozygosity; values in bold indicate significant deviation from Hardy-Weinberg equilibrium }(* * *: \mathrm{P}<}$ $0.01 ; * *: 0.01<\mathrm{P}<0.05 ; *: 0.05<\mathrm{P}<0.1)$. Significant linkage disequilibrium was detected between seven pairs of loci ( $<00,01)$, i.e. PS05-Pis07, PS05-Pis17, Pis16-Pis17, Pis07-Pis18, PS05-Pis21, Pis16-Pis23, and between Pis17-Pis23. 
Table 2 Polymerase Chain Reaction conditions.

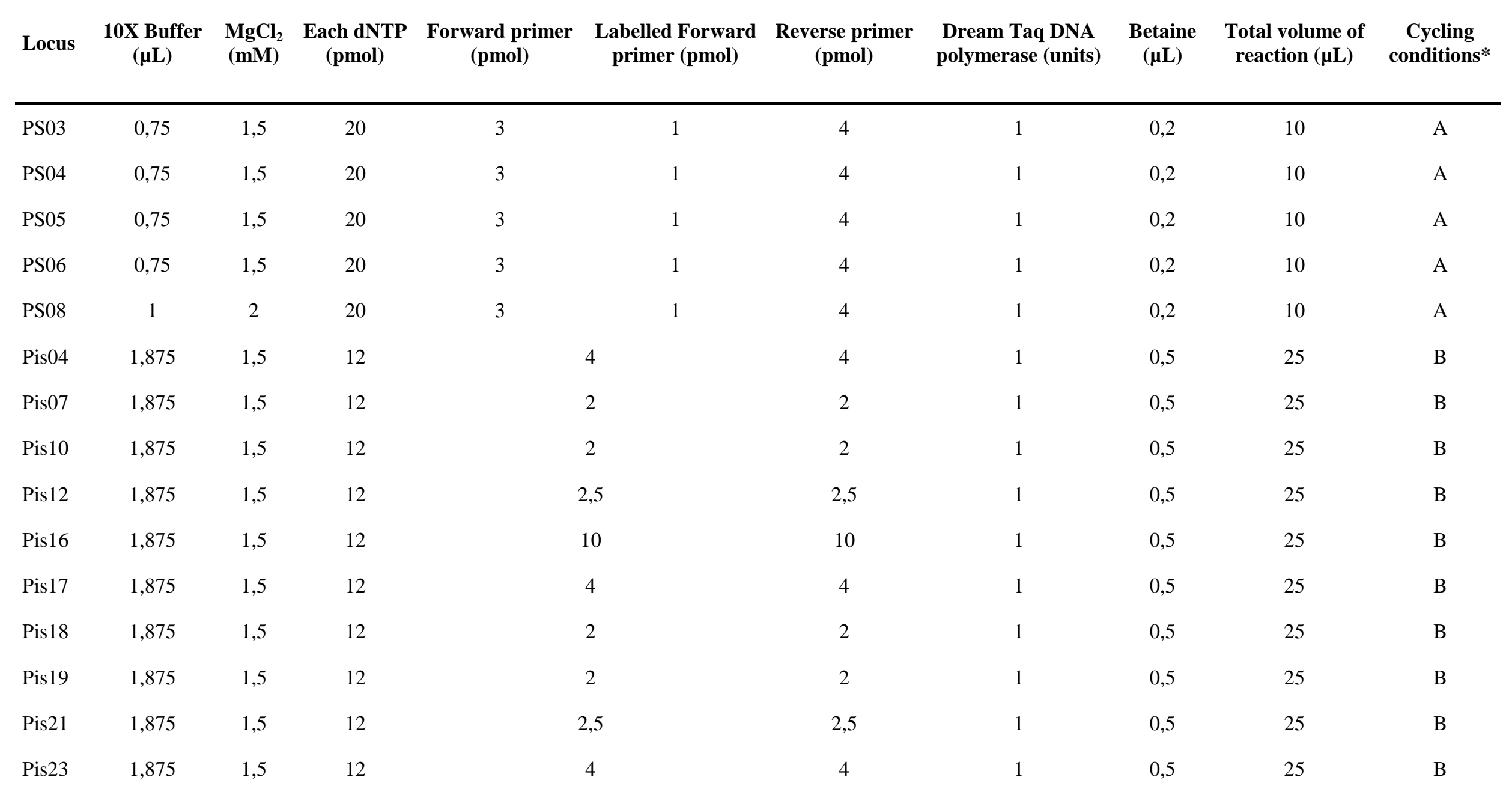

${ }^{*}$ Cycling conditions used were either A: denaturing at $94^{\circ} \mathrm{C}$ for $5 \mathrm{~min}$, followed by 40 cycles at $\left[94^{\circ} \mathrm{C}\right.$ for $45 \mathrm{~s}$, primer annealing temperature $(\mathrm{Ta})$ for $45 \mathrm{~s}, 72^{\circ} \mathrm{C}$ for $\left.1 \mathrm{~min}\right]$ and a final elongation at $72^{\circ} \mathrm{C}$ for $5 \mathrm{~min}$; or B: denaturing at $95^{\circ} \mathrm{C}$ for $10 \mathrm{~min}$, followed by 40 cycles at $\left[95^{\circ} \mathrm{C}\right.$ for $30 \mathrm{~s}, 55^{\circ} \mathrm{C}$ for $30 \mathrm{~s}, 72^{\circ} \mathrm{C}$ for $\left.1 \mathrm{~min}\right]$ and a final elongation at $72^{\circ} \mathrm{C}$ for $10 \mathrm{~min}$. 
Table 3 Cross-species amplification results for Pissodes spp.: number of successful amplifications / number of alleles in the taxon.

\begin{tabular}{|c|c|c|c|c|c|c|c|c|c|c|c|c|c|c|c|c|c|c|}
\hline Species & Host plant & Country & $N$ & PSO3 & PS04 & PSO5 & PS06 & PS08 & Pis04 & Pis07 & Pis10 & Pis12 & Pis16 & Pis17 & Pis18 & Pis19 & Pis21 & Pis23 \\
\hline P.castaneus & Pinus sp. & France & 2 & $2 / 1$ & $2 / 2$ & $1 / 1$ & $2 / 3$ & $2 / 1$ & $2 / 1$ & $2 / 3$ & 0 & $2 / 3$ & 0 & 0 & $2 / 4$ & 0 & $2 / 1$ & 0 \\
\hline P.piceae & Picea abies & France & 2 & $1 / 2$ & 0 & $2 / 3$ & $2 / 1$ & $2 / 1$ & $2 / 1$ & $2 / 1$ & 0 & $2 / 1$ & 0 & 0 & $1 / 2$ & 0 & $2 / 1$ & 0 \\
\hline P.pini & $\begin{array}{c}\text { Pinus } \\
\text { uncinata }\end{array}$ & France & 2 & 0 & $2 / 1$ & $1 / 2$ & $2 / 1$ & $1 / 1$ & $2 / 1$ & $2 / 1$ & 0 & $1 / 1$ & 0 & 0 & $1 / 2$ & 0 & 0 & 0 \\
\hline P.nemorensis & Pinus patula & $\begin{array}{l}\text { South } \\
\text { Africa }\end{array}$ & 1 & $1 / 1$ & $1 / 1$ & $1 / 1$ & $1 / 1$ & $1 / 1$ & $1 / 1$ & $1 / 1$ & 0 & 0 & $1 / 1$ & 0 & 0 & 0 & 0 & 0 \\
\hline P.strobi & Pinus sp. & Canada & 1 & 0 & $1 / 2$ & $1 / 1$ & $1 / 2$ & $1 / 2$ & $1 / 2$ & $1 / 1$ & 0 & 0 & 0 & 0 & 0 & 0 & $1 / 1$ & 0 \\
\hline P.punctatus & $\begin{array}{c}\text { Pinus } \\
\text { armandii }\end{array}$ & China & 1 & 0 & $1 / 2$ & 0 & 0 & 0 & $1 / 1$ & $1 / 1$ & 0 & 0 & $1 / 1$ & 0 & 0 & $1 / 2$ & 0 & 0 \\
\hline P.yunanensis & $\begin{array}{c}\text { Pinus } \\
\text { yunnanensis }\end{array}$ & China & 1 & 0 & $1 / 2$ & 0 & $1 / 1$ & 0 & $1 / 1$ & $1 / 1$ & 0 & 0 & 0 & 0 & $1 / 2$ & 0 & 0 & 0 \\
\hline
\end{tabular}

